AGRITECH, Vol. 37, No. 2, Mei 2017, Hal. 199-204

DOI: http://doi.org/10.22146/agritech.25926

ISSN 0216-0455 (Print), ISSN 2527-3825 (Online)

Tersedia online di https://jurnal.ugm.ac.id/agritech/

\title{
Kinetika Oksidasi Protein Ikan Kakap (Lutjanus sp) Selama Penyimpanan
}

\author{
Kinetic of Protein Oxidation from Fish Snapper (Lutjanus sp) during Storage \\ Rahim Husain 1 , S. Suparmo², Eni Harmayani², Chusnul Hidayat ${ }^{2}$ \\ ${ }^{1}$ Fakultas Ilmu-Ilmu Pertanian, Universitas Negeri Gorontalo, Jl. Jenderal Sudirman, No. 6, Kota Gorontalo 96182, Indonesia \\ ${ }^{2}$ Departemen Teknologi Pangan dan Hasil Pertanian, Fakultas Teknologi Pertanian, Universitas Gadjah Mada, \\ Jl. Flora No. 1, Bulaksumur, Yogyakarta 55281, Indonesia \\ Email: imrahim76@yahoo.co.id
}

Submisi: 10 Juli 2015; Penerimaan: 17 Mei 2016

\begin{abstract}
ABSTRAK
Protein ikan mudah rusak akibat oksidasi selama penyimpanan. Kecepatan reaksi oksidasi dapat didekati melalui orde ke nol maupun orde pertama. Penelitian ini bertujuan untuk mempelajari oksidasi selama penyimpanan dengan menentukan besaran energi aktivasi (Ea) dan konstanta perubahan (k). Hasil menunjukkan bahwa nilai $\mathrm{k}$ meningkat dari 0,0617 menjadi 0,311 dengan peningkatan suhu dari $0{ }^{\circ} \mathrm{C}$ ke $40{ }^{\circ} \mathrm{C}$. Energi aktivasi reaksi oksidasi yang menyebabkan terjadinya oksidasi protein adalah $42,015 \mathrm{Kj} / \mathrm{mol} . \mathrm{K}$ untuk orde nol. Kinetika peningkatan protein karbonil: semakin tinggi suhu penyimpanan protein ikan kakap (Lutjanus sp) semakin besar nilai konstanta (k) yang diperoleh. Studi kinetika juga memperlihatkan bahwa peningkatan laju reaksi kerusakan oksidasi protein ikan kakap selama penyimpanan mengikuti reaksi orde ke nol atau reaksi berjalan lambat.
\end{abstract}

Kata kunci: Energi aktivasi; protein ikan; kinetika reaksi ordo nol; reaksi orde pertama

\begin{abstract}
Fish protein is oxidased easily during storage. The oxidation reaction rate can be approached through the order to zero or first order. The objective of this research was to study the oxidation rate during storage by determining the amount of activation energy $(\mathrm{Ea})$ and constant change $(\mathrm{k})$. The results showed that the increased of temperature storage from 0 ${ }^{\circ} \mathrm{C}$ to $40{ }^{\circ} \mathrm{C}$ can increased the $\mathrm{k}$ value from 0.0617 to 0.311 . The carbonyl content of red snapper protein isolate can be increased to higher level as storage temperature increase to $40^{\circ} \mathrm{C}$ with higher level increase at higher temperature. The activation energy of oxidation reactions that cause oxidation of the protein is $42.015 \mathrm{Kj} / \mathrm{mol} . \mathrm{K}$ to zero order. Kinetics increase in protein carbonyls: the higher the temperature storage protein isolate red snapper (Lutjanus $s p$ ), the greater the value of a constant $(\mathrm{k})$ is obtained. Kinetics studies show that an increase in the rate of reaction of oxidative damage fish protein during storage by following zero order reactions.
\end{abstract}

Keywords: Activation energy; fish protein; kinetics reaction of zero order; first-order reaction

\section{PENDAHULUAN}

Protein ikan mempunyai nilai ekonomi tinggi bagi industri ikan, memperbaiki stabilitas dan fungsional dari produk ikan. Protein ikan dalam bentuk konsentrat telah digunakan sebagai suplementasi bahan pangan berprotein rendah untuk golongan rawan gizi (Wang dkk., 2010). Menurut Mercier dkk. (2011) penelitian oksidasi protein relatif baru dan pembentukan karbonil merupakan salah satu perubahan yang paling menonjol dalam protein teroksidasi. 
Selanjutnya Vareltzis dkk. (2008) dan Kjarsgard dkk. (2006) menyatakan jika protein karbonil yang dihasilkan oleh oksidasi langsung dari rantai samping asam amino, karbonil eksogen dapat dihubungkan ke protein dengan reaksi 4-OH nonenal, atau dengan reaksi mengurangi gula. Sedangkan Baron dkk. (2007) menyatakan bahwa oksidasi pada protein juga menyebabkan penurunan kelompok sulfhidril, oksidasi aromatik yang menginduksi modifikasi dari sifat biologis seperti hilangnya aktivitas enzimatik, perubahan kelarutan dan/atau peningkatan kerentanan proteolitik.

Degradasi nutrisi dapat dihitung dengan cara yang sama oleh inaktivasi mikroba. Secara umum kinetika degradasi nutrisi mengikuti orde nol dan orde pertama. Kinetika telah digunakan dalam ilmu makanan untuk menggambarkan seberapa cepat reaksi berubah jika produk disimpan pada suhu tinggi. Jika parameter kinetik diketahui, maka kinetika dapat digunakan untuk memprediksi umur simpan produk. Umumnya, degradasi nutrisi di bawah kondisi isotermal dapat diwakili oleh Persamaan 1.

$$
\frac{d c}{d t}=-k(C)^{n}
$$

di mana $\mathrm{k}$ adalah laju konstan, $\mathrm{C}$ adalah indikator kuantitatif bahan pada waktu $\mathrm{t}$, dan $\mathrm{n}$ adalah orde. Bentuk terintegrasi untuk orde nol, pertama dan kedua model kinetik tercantum dalam persamaan (2) dan (3), masing-masing.

$$
\begin{aligned}
& \text { zero - order : } C_{t}=C_{0}-k \cdot t \\
& \text { first }- \text { order: } \ln \frac{C t}{C o}=-k \cdot t
\end{aligned}
$$

dimana Co merupakan nilai awal pada waktu nol, Ct adalah nilai pada waktu t, $\mathrm{k}$ adalah laju konstan. Persamaan Arrhenius (Persamaan 4) biasanya diterapkan untuk menggambarkan laju reaksi suhu konstan:

$$
k=k_{o} \cdot e^{-\frac{E_{o}}{R T}}
$$

Sebuah plot konstan pada skala semi-logaritmik sebagai fungsi temperatur absolut timbal balik (1/T) harus memberikan garis lurus, dan energi aktivasi ditentukan sebagai kemiringan garis dikalikan dengan konstanta gas $(\mathrm{R})$.

Penelitian ini bertujuan untuk mempelajari kinetika reaksi oksidasi protein ikan selama penyimpanan dengan menentukan besaran energi aktivasi (Ea) dan konstanta perubahan (k) yang memungkinkan untuk memprediksi tingkat kerusakan karena oksidasi protein ikan berdasarkan persamaan kinetika arrhenius.

\section{METODE PENELITIAN}

\section{Bahan Baku}

Bahan baku ikan kakap diperoleh dari tempat pelelangan ikan (TPI) Kobong, Kelurahan Kaligawe, Semarang, Jawa Tengah, Indonesia. Ikan disiangi dan diambil dagingnya, sementara bagian kepala, insang, tulang, dan bagian tubuh lainnya dibuang. Bahan-bahan kimia yang digunakan adalah $\mathrm{HCl} 0,1 \mathrm{~N}, \mathrm{NaOH}, 0,1 \mathrm{~N}, \mathrm{KOH} 1 \mathrm{~N}, 2,4$ dinitrophenilhydrazil $(\mathrm{DNPH})$, methanol, dan aseton murni dari Merck KgaA (Darmstadt, Jerman).

\section{Penyiapan Sampel Protein Ikan}

Sebanyak $500 \mathrm{~g}$ daging ikan kakap (Lutjanus $s p$ ) dihomogenkan dengan air dingin sebanyak 3,5 liter. Setelah itu ditambahkan $\mathrm{HCl}$ untuk mengekstraksi jumlah protein yang terdapat pada daging ikan. Daging ikan yang telah dihomogenkan diberi $\mathrm{HCl}$ dengan $\mathrm{pH}$ 2,5 kemudian, disentrifugasi (tahap satu) pada suhu $4{ }^{\circ} \mathrm{C}$ dengan kecepatan $4000 \mathrm{rpm}$ yang menghasilkan endapan. Endapan kemudian diberi $\mathrm{NaOH}$ sampai $\mathrm{pH}$ mencapai titik isolektrik yakni 5,5. Pada $\mathrm{pH}$ isolektrik ini, disentrifugasi (tahap dua) untuk memperoleh endapan yang kedua. Endapan tersebut di-freeze drying selama 3 hari untuk mendapatkan hasil protein ikan atau konsentrat protein ikan.

\section{Pengaruh Suhu dan Waktu terhadap Angka Karbonil}

Masing-masing protein ikan sebesar $100 \mathrm{~g}$ disimpan pada suhu $0,10,2030$, dan $40^{\circ} \mathrm{C}$. Sampel pada penyimpanan suhu $0{ }^{\circ} \mathrm{C}$ dilakukan sampling pada hari ke $0,10,20,30,40$, $50,60,70,80$, dan 90 . Sampel pada penyimpanan suhu $10^{\circ} \mathrm{C}$ dilakukan sampling pada hari ke $0,5,10,15,20,25,30,35$, 40 dan 45. Sampel pada penyimpanan suhu $20^{\circ} \mathrm{C}$ dilakukan sampling pada hari ke 0, 3, 6, 9, 12, 15, 18, 21, 24, dan 27. Sampel pada penyimpanan suhu $30^{\circ} \mathrm{C}$ dilakukan sampling pada hari ke 2, 4, 6, 8, 10,12, 14, 16, dan 18. Sampel pada penyimpanan suhu $40{ }^{\circ} \mathrm{C}$ dilakukan sampling pada hari ke 0 , $1,2,3,4,5,6,7,8$, dan 9. Sampel dinalisa angka karbonil.

\section{Persamaan Matematik Oksidasi Protein Ikan Kakap (Lutjanus sp)}

$$
P+O=F e 2 \stackrel{k . p 1}{\longrightarrow} R o * \stackrel{k . p 2}{\longrightarrow} R
$$

Diketahui bahwa oksidasi protein dapat menghasilkan protein karbonil sebagai akibat dari reaksi oksigen spesies (ROS) yang menghasilkan radikal peroksil, radikal hidroperoksida dan yang selanjutnya, akan menghasilkan radikal alkoksil sebagai pemicu dari $\mathrm{Fe}^{2+}$. Hal ini dapat ditunjukkan oleh Persamaan 6, 7, 8, dan 9. 
$(d(P))(d t=)-k \cdot p 1[P][O]$

$(d(O))(d t=k \cdot p i[P][O])$

$\left(d\left(R O^{*}\right)\right)\left(d t=k . p 2\left[R O^{*}\right]\right.$

$(d(R))(d t=k \cdot p 2[R])$

Laju reaksi dari semua reaksi ini adalah k.p dan k.p $_{2}$ yang menghasilkan protein karbonil sebagai produk akhir.

\section{Analisis Proksimat}

Analisis kimia: proksimat kadar air, kadar abu, protein dan lemak berdasarkan AOAC (2006), Fe menggunakan AAS (Khan dkk., 2009).

\section{Analisis Kadar Protein Karbonil}

Ditimbang $(0,5 \mathrm{~g})$ protein ikan, diencerkan menjadi $250 \mathrm{ml}$ dengan akuades. Ditambahkan dengan 2,4 dinitrophenilhidrazine dan 1 tetes $\mathrm{HCl}$ pekat. Dipanaskan selama 30 menit pada suhu $50{ }^{\circ} \mathrm{C}$ dan didinginkan serta ditambahkan lagi $8 \mathrm{ml} \mathrm{KOH} 1 \mathrm{~N}$. Setelah itu, absorbansi ditera pada panjang gelombang $480 \mathrm{~nm}$ (Lappin dan Clark, 1951).

$$
\% \text { kadar karbonil }=\frac{X x F P}{m g \text { sampel }} \times 100 \%
$$

\section{HASIL DAN PEMBAHASAN}

\section{Proksimat Ikan Segar}

Berdasarkan Tabel 1 kadar protein ikan kakap segar dalam penelitian ini adalah $(18,77 \%$; BB), yang dilaporkan oleh Nurnadia dkk. (2011), Gooch dkk. (2013), dan El-Faer dkk. (2012), masing-masing 20,45\%, 19,7\% dan 19,30\%. Kandungan protein kasar pada ikan segar $(18,77 \%$; BB) dan pada protein ikan $(88,92 \%$; BK), hal ini menunjukkan bahwa $95,83 \%$ protein ikan berada pada fraksi protein murni (isolat).

Tabel 1. Proksimat, protein ikan dan kadar Fe ikan kakap (Lutjanus sp)*

\begin{tabular}{lrrrr}
\hline \multicolumn{1}{c}{ Parameter } & \multicolumn{2}{c}{ Daging segar } & & \\
& $\begin{array}{c}\text { Kadar } \\
\text { (BB) }\end{array}$ & $\begin{array}{r}\text { Kadar } \\
\text { (BK) }\end{array}$ & $\begin{array}{c}\text { Protein } \\
\text { ikan }\end{array}$ & $\begin{array}{c}\text { Gooch dkk., } \\
(2013)\end{array}$ \\
\hline Kadar air (\%; BB) & 78,39 & - & 7,20 & 78,90 \\
Kadar abu (\%; BK) & 1,58 & 4,11 & 1,46 & 1,10 \\
Protein (\%; BK) & 18,77 & 88,92 & 89,10 & 19,70 \\
Lemak (\%; BK) & 1,95 & 4,81 & 0,90 & 1,10 \\
Karbohidrat by & 0,30 & 2,16 & 0,00 & 0,10 \\
difference (\%; BK) & & & & \\
Fe (ppm) & 121,47 & - & 108,95 & - \\
\hline
\end{tabular}

*Keterangan: data berasal dari $3 \mathrm{x}$ ulangan
Perbedaan kandungan protein ikan sangat dipengaruhi oleh kesegaran bahan ikan yang digunakan sebagai faktor kritis dalam mengasilkan isolat, metode isolasi/ekstraksi yang digunakan, homogenisasi daging saat prosesing, rasio ikan dan pelarut (viskositas) yang digunakan, lama ekstraksi, waktu dan suhu prosesing dan kelarutan protein (Shaviklo, 2006).

Tabel 1 menunjukkan pula bahwa protein ikan mengandung Fe sebesar 89,69\% dari total Fe daging segar ikan (121,47 ppm). Okada (2010) menjelaskan warna daging ikan disebabkan kandungan $\mathrm{Fe}$ dalam daging sangat tinggi karena kaya hemoprotein $(80 \%)$ terutama mioglobin dan hemoglobin. Berdasarkan Okada (1990) tersebut, kandungan hemoproteinnya daging ikan kakap rendah sehingga dagingnya berwarna putih. Dengan asumsi Okada (1990), maka secara natural daging ikan kakap daging putih tidak mudah mengalami oksidasi karena sedikitnya prooksidan, walaupun Fe dalam protein ikan masih tinggi (89,96\% dari total Fe ikan).

\section{Profil Asam Amino}

Tabel 2 terlihat bahwa protein ikan kakap memiliki kandungan asam amino yang rentan terhadap kerusakan oksidatif seperti histidin, alanin, tirosin, metionin, valin, dan phenilalanin. Menurut Konusu dan Yamaguchi (2013); dan Sikorski (2010) bahwa protein ikan mengandung 18 asam amino baik esensial maupun non esensial. Asam-asam amino tersebut antara lain: asam aspartat, asam glutamat, serin, histidin, arginin, glisin, treonin, alanin, tirosin, triptofan,

Tabel 2. Hasil analisis komposisi asam amino protein ikan kakap (Lutjanus sp)*

\begin{tabular}{lc}
\hline \multicolumn{1}{c}{ Asam amino } & Protein ikan (\%) \\
\hline Asam aspartat (Asp) & 21,96 \\
Asam glutamat (Glu) & 29,74 \\
Serin (S) & 2,17 \\
Glisin (Gly) & 3,08 \\
Alanin (Ala) & 4,65 \\
Histidin (His) & 1,54 \\
Aginin (Arg) & 4,72 \\
Tirosin (Tyr) & 1,40 \\
Metionin (Met) & 1,00 \\
Valin (Val) & 1,41 \\
Fenilalanin (Phe) & 1,25 \\
Isoleusin (Ile) & 1,33 \\
Leusin (Leu) & 6,47 \\
Lisin (Lys) & 7,45 \\
Treonin (Thr) & 0,09 \\
* Dianalisis dengan HPLC Shimadzu SPD-M10A (Kromatogram standar \\
asam amino)
\end{tabular}


sistein, metionin, valin, phenilalanin, isoleusin, leusin, dan lisin.

Berdasar hasil analisis yang dilakukan hanya teridentifikasi 15 asam amino sedangkan 3 asam amino yaitu triptofan, sistein dan prolin tidak teridentifikasi disebabkan karena triptofan akan mengalami kerusakan bila dilakukan hidrolisis asam amino dengan mengunakan asam $(\mathrm{HCl})$. Sistein yang kaya akan elektron mudah mengalami kerusakan oksidatif oleh adanya serangan dari radikal maupun non radikal pengoksida (Davies, 2005).

Stadman dan Levine (2003), menyatakan bahwa rantai samping aromatik dari asam-asam amino penyusun protein merupakan target yang potensial dari berbagai senyawa oksigen reaktif seperti fenilalanin, tirosin, triptofan dan histidin. Davies (2005) menyatakan bahwa rantai samping alifatik juga merupakan target utama senyawa oksigen reaktif berupa asam amino leusin, glisin, valin, lisin, prolin, arginin, isoleusin, metionin, dan sistein.

\section{Pengaruh Suhu dan Waktu terhadap Angka Karbonil}

Protein karbonil merupakan salah satu 'biomarker' terjadinya oksidasi protein (Yan dkk., 1997) dan digunakan sebagai salah satu indikator terjadinya kerusakan/modifikasi protein yang disebabkan oleh radikal-radikal oksigen (Adams dkk., 2001).

Angka karbonil meningkat 4,3 kali pada suhu $0{ }^{\circ} \mathrm{C}$ sedangkan pada suhu $10,20,30$, dan $40{ }^{\circ} \mathrm{C}$ angka karbonil meningkat masing-masing menjadi 4,8; 5,0; 7,2; dan 9,2 kali $\mathrm{nmol} / \mathrm{g}$ sampel.

Peningkatan protein karbonil disebabkan pada protein ikan kakap dalam penelitian ini secara natural masih mengandung besi (Fe) sehingga dapat memicu kerusakan oksidasi. Walaupun dengan asumsi kadar asam lemak dalam

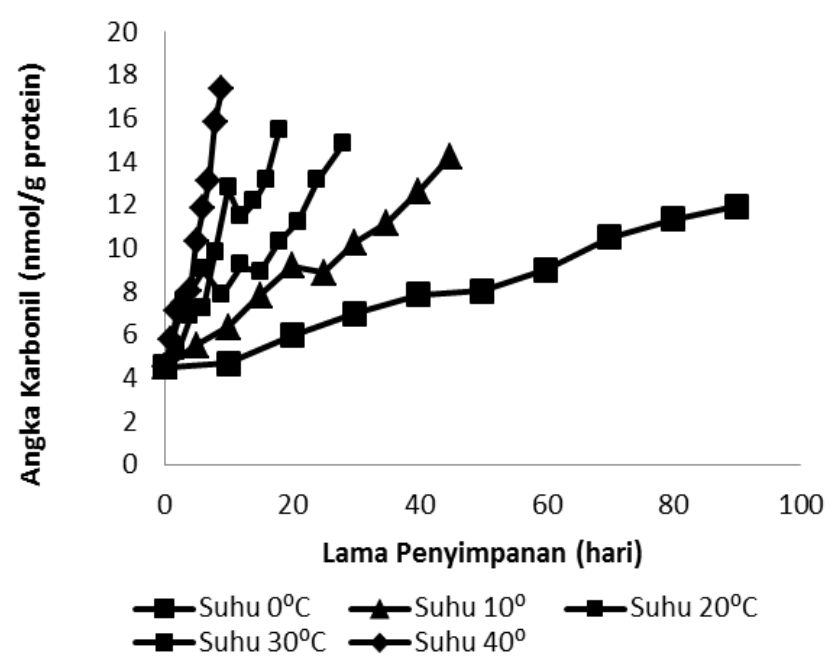

Gambar 1. Oksidasi angka karbonil protein ikan kakap (Lutjanus $s p$ ) selama penyimpanan isolat protein sangat rendah sehingga dapat diabaikan, oksidasi lipida yang dikatalisa oleh Fe natural masih dapat terjadi. Perlakuan suhu $20-40{ }^{\circ} \mathrm{C}$ (radiasi panas) meningkatkan kerusakan oksidasi tersebut. Hal ini terbukti pada hasil riset ini terutama pada suhu penyimpanan $30^{\circ} \mathrm{C}$ dan $40^{\circ} \mathrm{C}$ laju reaksi cenderung linier.

\section{Kinetika Perubahan Angka Karbonil}

Nilai $\mathrm{k}$ meningkat dengan peningkatan suhu penyimpanan. $\mathrm{K}$ meningkat dari 0,0863 menjadi 1,4066 dengan peningkatan suhu dari 0 ke $40{ }^{\circ} \mathrm{C}$ (Tabel 3). Konstanta laju (k) perubahan luas (y) menunjukkan nilai perubahan angka karbonil selama penyimpanan.

Besarnya energi aktivasi pembentukan karbonil menurut reaksi orde nol adalah 52,022,26 J/mol.k atau 52,02 Kj/mol.k. Sedangkan reaksi orde pertama adalah 43,364,9 J/mol.k atau 43,37 kj/mol.k. Prediksi angka karbonil protein ikan kakap menurut reaksi orde nol dan reaksi orde pertama dapat dilihat pada Gambar 2. Kenaikan angka karbonil menunjukkan reaksi mengikuti orde ke nol. Hal ini disebabkan reaksi berjalan lambat pada suhu kamar dan tidak ada reaksi oksidasi yang disebabkan oleh fotooksidasi.

Tabel 3. Persamaan linear sebagai fungsi waktu pada angka karbonil

\begin{tabular}{cccc}
\hline Suhu $\left({ }^{\circ} \mathrm{C}\right)$ & Persamaan linear & $\mathrm{R}^{2}$ & $\mathrm{~K}$ \\
\hline 0 & $\mathrm{Y}=-0,0863 \mathrm{t}+4,2108$ & 0,987 & 0,0863 \\
10 & $\mathrm{Y}=-0,2043 \mathrm{t}+4,4738$ & 0,981 & 0,2043 \\
20 & $\mathrm{Y}=-0,2978 \mathrm{t}+5,5782$ & 0,894 & 0,2978 \\
30 & $\mathrm{Y}=-0,5939+4,4857$ & 0,935 & 0,5940 \\
40 & $\mathrm{Y}=-1,4066+3,8169$ & 0,967 & 1,4066 \\
\hline
\end{tabular}

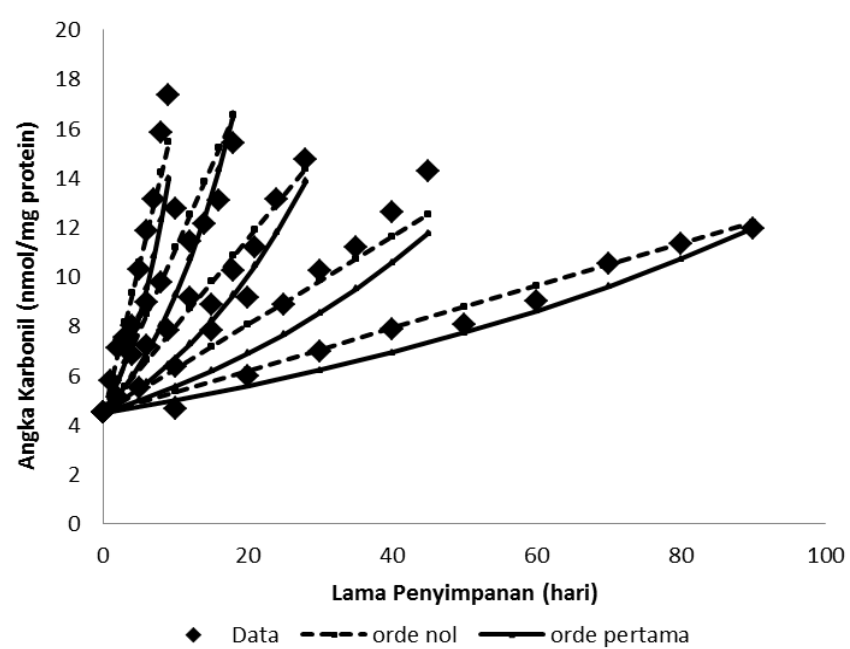

Gambar 2. Hubungan antara data (konsentrasi bahan), model reaksi orde nol, dan model reaksi orde pertama pada kadar karbonil protein ikan 
Menurut Kjarsgard dkk. (2006) dan Baron dkk. (2007) dengan adanya kenaikan suhu dan lama penyimpanan menyebabkan protein karbonil meningkat. Adams dkk. (2001) serangan radikal hidroksil yang dihasilkan dari degradasi $\mathrm{H}_{2} \mathrm{O}_{2}$ dengan kehadiran $\mathrm{Fe}^{2+}$ atau $\mathrm{Cu}^{2+}$ mengakibatkan terjadinya kerusakan protein yang ditandai dengan terbentuknya protein karbonil.

\section{KESIMPULAN}

Angka karbonil meningkat 4,3 kali pada suhu $0{ }^{\circ} \mathrm{C}$ pada suhu $10,20,30$, dan $40^{\circ} \mathrm{C}$ angka karbonil meningkat masingmasing menjadi 4,8: 5,0: 7,2: dan 9,2 kali nmol/g sampel. Energi aktivasi yang dibutuhkan dalam reaksi oksidasi protein ikan pada reaksi orde nol selama penyimpanan adalah $42,015 \mathrm{kj} / \mathrm{mol} . K$. Kinetika pembentukan kadar karbonil pada orde reaksi pertama adalah $34818,9 \mathrm{j} / \mathrm{mol} . \mathrm{k}$ atau 34,818 kj/mol.k yang memperlihatkan laju pembentukan kadar karbonil lambat atau reaksi yang berlangsung adalah reaksi orde pertama. Dengan adanya kenaikan suhu dan lama penyimpanan menyebabkan protein karbonil meningkat dan serangan radikal hidroksil yang dihasilkan dari degradasi $\mathrm{H}_{2} \mathrm{O}_{2}$ dan kehadiran $\mathrm{Fe}^{2+}$ atau $\mathrm{Cu}^{2+}$ mengakibatkan terjadinya kerusakan protein yang ditandai dengan terbentuknya protein karbonil.

\section{DAFTAR PUSTAKA}

Adams, S., Green, P., Claxton, R., Simcox., Williams, M.V. dan Walsh, K. (2001). Reactive carbonyl formation by oxidative and non-oxidative pathways. Frontiers in Bioscience 6: 17-24.

AOAC. (2006). Official Methods of Analysis of the Association of Official Analytical Chemistry. Association of Official Anaytical Chemistry Washington, DC.

Baron, P.C., Kjaesgrad, I.V.H., Jessen, F. dan Jacobsen, C. (2007). Protein and lipid oxidation during frozen storage of rainbow trout (Oncorhynchus mykiss). Journal of Agricultural and Food Chemistry 55: 8118-8125.

Davies, M.J. (2005). The oxidative envioronment and protein demage. Biochemica et Biophysica Acta 1703: 93-109.

El-Faer, M.Z., Rawdah, T.N., Attar, K.M. dan Arab, M. (2012). Mineral and proximate composition of some commercially important fish of the arabian gulf. Food Chemistry 45: 95-98.

Gooch, J.A., Hale, M.B., Brown, T.Jr., Bonnet, J.C., Brand, C.G. dan Regier, L.W. (2013). Proximate and fatty acid composition of 40 southeastern U.S. finfish species.U.S.
Department of Commerce National Oceanic and Atmospheric dministration National Marine Fisheries Service.

Khan, Z.I., Ashraf, M., Ahmad, K., Valeem, E.E dan Mcdowell, L.R., (2009). Mineral status of forage and its relationship with that of plasma farm animals in southern Punjab, Pakistan. Pakistan Journal of Nutrition 41: 67-72.

Kjaersgard, I.V.H., Norrelykke, M.R., Baron, C.P. dan Jessen, F. (2006). Identification of carbonylated protein in frozen rainbow trout (Oncorhychus mykiss) fillets and development of protein oxidation during frozen storage. Journal Agricultural and Food Chemistry 54: 94379446.

Konusu, S. dan Yamaguchi, K. (2013). The Flavor Components in Fish and Shelfish. Chemistry and Biochemistry of Marine Food Product. The AVI Publishing Company. Inc. Westport. Connexticut.

Labuza, T.P. dan Riboh, D. (1982). Theory and application of kinetics to the prediction of nutrient losses in food. Food Technology 7: 66-74.

Lappin, G.R. dan Clark, L.C. (1951). Colorimetric methods for determination of trace carbonyl compound. Analytical Chemistry 23: 541-542.

Mercier, P., Gatelier, P., Vincent, A. dan Renerre (2011). Lipid and protein oxidation in microsomal fraction from turkeys: influence of dietary fat and vitamin $\mathrm{E}$ supplementation. Meat Science 58: 125-134.

Nurnadia, A.A., Azrina, A. dan Amin, I. (2011). Proximate composition and energetic value of selected marine fish and shellfish from the west coast of peninsular Malaysia. International Food Research Journal 18: 137-148.

Okada, M. (2010). Fish and raw material. In science of processing marine food product. Vol. I. editor. T. Motohiro, H. Kadota. K. Hashimoto. M. Katayama and T. Tokunaga. Japan International Coorporation Agency. Hyoga International Centre Japan.

Shaviklo, G.R. (2006). Quality Assessment of Ash Protein Isolates using Surim Standard Methods. Reykjavik, Ice/ and: The United Nations University.

Sikorski, Z.E. (2010). Seafood: Resource, Nutritional Composition and Preservation. CRC Press Inc., Boca Rotan Florida. P:39.

Stadman, E.R. dan Levine, R.L. (2003). Free radical-mediatet oxidation free amino acids residues in proteins. Amino Acids 25: 207-218. 
Theodore, L., Brown, H., LeMay, E. dan Bursten, B.E. (2000). Chemistry: The Central Science, $8^{\text {th }}$ Edition. Prentice Hall College Div.

Tokur, B. dan Korkmaz, K. (2007). The effects of an ironcatalyzed oxidation system on lipids and proteins of dark muscle fish. Food Chemistry 104: 754-760.

Vareltzis, P., Hultin, H.O. dan Autio, W.R. (2008). Hemoglobin-mediated lipid oxidation of protein isolates obtained from cod and haddock white muscle as affected by citric acid, calcium chloride and $\mathrm{pH}$. Food Chemistry 108: 64-74.
Wang, T., Jónsdóttir, R., Kristinsson, G.H., Thorkelsson, G., Jacobsen, C., Hamaguchi,Y.P. dan Ólafsdóttir, G. (2010). Inhibition of haemoglobin-mediated lipid oxidation in washed cod muscle and cod protein isolates by (Fucus vesiculosus) extract and fractions. Food Chemistry 123: 321-330.

Yan, L.J., Levine, R.L. dan Sohal, RS. (1997). Oxidative damage during aging targets mitochondrial aconitase. Journal Process Natlantic Academic Science USA 94: 11168-11172. 